\section{Technology transfer on the move}

Washington

SwEEPING changes designed to speed the commercial uptake of technology from US federal laboratories are expected to be signed into law this week by President Reagan as the culmination of a six-year effort by Congress to liberalize privatesector participation in federal research. Despite some earlier agency opposition, all 700-odd federally operated laboratories will in future be encouraged to carry out cooperative research with private companies, universities and state organizations, even assigning patent rights to collaborators when that will accelerate transfer. The stimulus for the new act was the perception that foreign competitors are making better use of US government research than is domestic industry.

More controversially, the Federal Technology Transfer Act of 1985 also obliges federal agencies to reward employee-inventors with not less than 15 per cent of patent royalties arising from their work, up to $\$ 100,000$ a year. Much of the balance will be set aside for education and incentive schemes for others who make important contributions.

By promising federal employees better personal gains for stimulating technology transfer, and by offering private industry the carrot of title to inventions, the new act provides incentives for both technology 'push' and 'pull'. It stipulates that laboratory managers should give preference to domestic industries and to small businesses.

The royalty-sharing provisions are nevertheless opposed by some of those with private interests in intellectual property. The Intellectual Property Owners' Association, a lobbying group for large research corporations, argues that such provisions unreasonably limit the discretion of managers to reward as they see fit. It also fears the law may encourage private industry to adopt the same rules, a prospect it views with horror.

The research pool to which US industry has now been given the keys is considerable. Federal laboratories employ one out every six scientists and engineers in the country, and consume an annual budget of $\$ 18,000$ million. Hitherto, the rules governing collaboration have been a patchwork, with only about a half of federal laboratories legally allowed to enter cooperative schemes. Some agencies, such as the Department of Energy and the National Aeronautics and Space Administration, already have cooperative projects; others, including the Departments of Defense and Agricuiture, have argued that they lack the legal authority to do so.

The new law puts all agencies on the same footing, and extends legislation pas- sed in 1980 and in 1984 that started the technology transfer ball rolling. The big contractor-operated laboratories run by the Department of Energy, such as Argonne and Los Alamos, were given formal authority to engage in collaborative research two years ago. Henceforth, all federal laboratories, whether contractoror government-operated, will be able to contribute and to receive resources as part of cooperative research agreements.

Another provision of the new law formally recognizes the Federal Consortium for Technology Transfer, which is intended to stimulate uptake of technology by providing training for laboratory staff and information for industry. An informal

\section{British research}

\section{Dispirited researchers on ropes}

BRITISH researchers last week responded despondently to the publication of two reports on the state of basic science commisioned by the Advisory Board for the Research Councils (ABRC). At a meeting in London to discuss the documents (see page 655), the leaders of the research and academic communities were more dispirited than hopeful

That "something modestly good" would come out of the publication of the two reports was the most that Sir David Phillips, chairman of ABRC, and Sir Peter

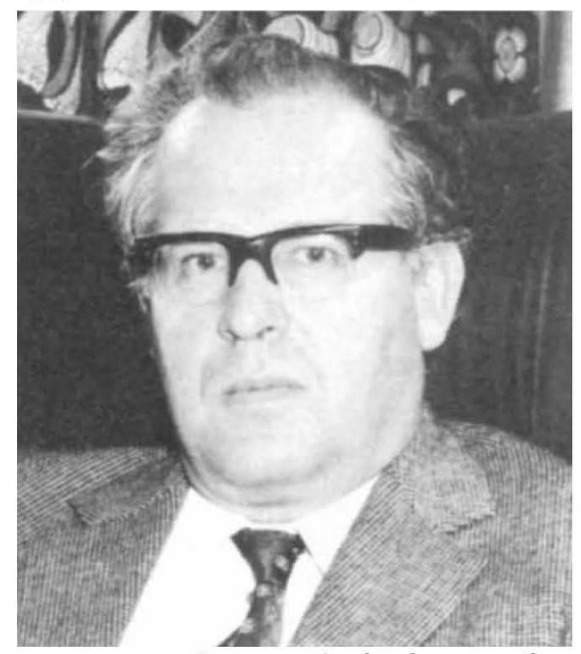

Swinnerton-Dyer: good value for money?

Swinnerton-Dyer, chairman of the University Grants Committee (UGC), could offer. Indeed, they seemed more ready to talk of further rationalization (newspeak for cuts and economies) than of strategies for raising support for British science. Nevertheless, Swinnerton-Dyer said the "sharp corners" of the reports would help in dealing with the Treasury.

Swinnerton-Dyer said that the concurrence of the conclusions of the ABRC predecessor organization has existed for more than a decade, but with a budget of only $\$ 200,000$ per year its influence has been limited. Its new incarnation has been given a permanent home in the National Bureau of Standards and $\$ 900,000$ to set up an electronic mail system linking the laboratories.

The new rules raise some awkward questions about the federal role. Brian Frost, director of technology transfer at Argonne National Laboratory, says laboratories will "have to walk a careful line" to ensure that federal funds are not used to support research that should properly be undertaken by industry. Similarly, nobody wants industry money to substitute for federal funds. But if correct decisions are made, Frost believes the result will save the taxpayer money while improving uptake.

Tim Beardsley

reports shows that "cheap methods work"; he would like to see the study extended from genetics and physics to all branches of British science. But he also warned against assuming that, if a field is shown to be weak or weakening, it should therefore be strengthened. Britain is still getting better value for its basic research spending than any other country, he says.

In Britain, the research councils and UGC should remain responsive, not directive. "I would rather back the aggregate of decisions by scientists in their twenties than the views of ageing committees, which are good only at deciding what should have been done 30 years ago."

On UGC's still-controversial procedures for deciding how to concentrate research in particular universities, Swinnerton-Dyer said that bibliometric indices would have no place in short-run assessment, that the valuable device of engaging experts from abroad in the assessment of research projects would require a much larger administrative budget than UGC now has, that UGC's present network of committees had the merit of being quick and flexible and that peer review would remain paramount in its decision-making.

ABRC may be able to use the hard data in the documents for future arguments with the Treasury. But Phillips also emphasized the necessity of choice: if Britain is responsible for roughly 5 per cent of the world's science, should it be in every field or should it simply back a few leading individuals, setting them up in larger units?

Britain's real problem, Phillips said, is that the rapid growth of the period 196673 had been followed by static budgets at a time when world scientific spending had doubled in a decade. "We can see enormous opportunities in Britain, but they cannot be met". 